\title{
Высотно-ландшафтные мезозоны и экзодинамические явления в Воронежском модельном регионе
}

\author{
С. В. Федотов $\bowtie$, С. В. Щербинина \\ Воронежский государственный университет, Российская Федерация \\ (394018, г. Воронеж, Университетская пл., 1)
}

\begin{abstract}
Аннотация: Цель исследования - выявить приуроченность экзодинамических явлений в Воронежском модельном регионе к высотно-ландшафтным мезозонам равнин. Материаль и методы. Исходными материалами для аналитических обобщений послужили натурные наблюдения на полустационарных полигонах, расположенных в Воронежском Подонье, экспедиционные маршрутные наблюдения, а также материалы дешифрирования космоснимков. Результаты и обсуждение. Полевые материалы, материалы фондов сельскохозяйственных предприятий, полустационарные наблюдения и результаты дистанционного зондирования показывают, что экзодинамические явления в Воронежском модельном регионе очень тесно связаны с высотно-ландшафтной дифференциацией равнинного рельефа. Например, водная и ветровая эрозия распространена повсеместно по территории области. Но чаще всего отмечается в границах возвышенно-денудационной и вершинно-водораздельной мезозонах на Среднерусской и Калачской возвышенностях. На Окско-Донской равнине ветровая эрозия отмечается в местах высокой распашки земель на низменно-гидрогенной мезозоне в верховьях рек Плавица, Битюг, Малый Эртиль. Там, где на Среднерусской возвышенности получила распространение вершинноводораздельная мезозона (200-250 метров) основные экзодинамические явления - водная эрозия и карстовая денудация. Заключение. Наши многочисленные исследования показывают, что в Воронежском модельном регионе встречается весь перечень экзодинамических явлений, известных в административных областях центра Русской равнины - овражная и водная эрозия, оползни, осыпи, обвалы, карстовая денудация, равнинные сели, камнепады.
\end{abstract}

Ключевые слова: высотная мезозональность, экзодинамические процессы, возвышенность, низменность, равнина, неотектоника.

Для цитирования: Федотов С.В., Щербинина С.В. Высотно-ландшафтные мезозоны и экзодинамические явления в Воронежском модельном регионе // Вестник Воронежского государственного университета. Серия География. Геоэкология, 2020, № 4, с. 69-78. DOI: https://doi.org/10.17308/geo.2020.4/3067

\section{ВВЕДЕНИЕ}

Воронежский регион и Воронежская область территориальные синонимы. По геотектоническому устройству и ландшафтной структуре - регион типичная для центра Русской равнины географическая область. На площади 54 тыс. км² здесь представлены возвышенные и низменные равнины, на которых устойчиво сложились ландшафты двух природных зон - типичной лесостепи и северной степи.
Крайний запад и юг региона занимают Среднерусская и Калачская возвышенности. На их водоразделах абсолютные отметки высот практически редко опускаются ниже 190-200 метров. Восточная часть области занята Окско-Донской низменностью. Абсолютные отметки на Окско-Донской равнине не часто поднимаются к 160-180 метрам. На возвышенной части области располагаются полностью или частично Семилукский, Хохольский, Нижнедевицкий, Острогожский, Репьевский, Лискинский (частично), Каменский, Россошанс-

() Федотов С. В., Щербинина С.В., 2020

Федотов Сергей Владимирович, e-mail: fsv777@ yandex.ru

cc) (i) Контент доступен под лицензией Creative Commons Attribution 4.0 License. 
кий, Подгоренский, Верхнемамонский (частично), Богучарский, Калачеевский, Воробьевский, Бутурлиновский, Таловский (частично) и Рамонский (частично) муниципальные районы. Остальные находятся на Окско-Донской низменности.

Полный спектр явлений экзодинамики (ветровая и водная эрозия, карст, оползни, солифлюкция, камнепады, равнинные сели, осыпи, обвалы) встречаются в муниципальных районах, располагающихся на Среднерусской и Калачской возвышенностях. На Окско-Донской низменной равнине водные эрозионные и оползневые процессы в основном приурочены к полосе речных долин Битюга, Воронежа, Икорца, Хопра, Вороны. Центральные части Окско-Донской низменности испытывают погружение до 2 мм в год. Следствие погружения - замкнутые и полузамкнутые суффозионные западины, и гидроморфные процессы в почвенном покрове.

Западинный микрорельеф на плоскоместьях востока области чаще всего встречается в Верхнехавском, Панинском, Аннинском, Новоусманском, Эртильском и Терновском муниципальных районах. На надпойменных террасах Окскодонских рек сохраняются крупные для центра Русской равнины древние котловины, занятые озерами-старицами: Ильмень - Голова (Новохоперский район), Ильмень, Моховое, Погарское (Поворинский район).

\section{МАТЕРИАЛЫ И МЕТОДЫ ИССЛЕДОВАНИЯ}

Цель исследования - выявить приуроченность разнообразных экзодинамических явлений к ландшафтно-высотным мезозонам равнин.

Исходными материалами для аналитических обобщений послужили натурные наблюдения на полустационарных полигонах, расположенных в Воронежском Подонье [5], экспедиционные маршрутные наблюдения, а также материалы дешифрирования космоснимков.

Как показывает многолетнее изучение высотно-ландшафтных мезозон в центре Русской равнины, их существование объясняется двумя группами природных факторов. К числу ведущих факторов относится геотектоническое устройство, скорректированное в неоген-четвертичный период - неотектоникой, плейстоценовая история и эрозионно-долинно-балочное расчленение. Литология пород, слагающих Воронежский регион, и климатические условия, факторы сопутствующие.

\section{РЕЗУЛЬТАТЫ И ОБСУЖДЕНИЕ}

Неотектоника, ландмафтно-высотные мезозоны и экзодинамические явления. На Среднерус- ской возвышенности известны три неотектонических поднятия - Еманчинское в бассейнах рек Ведуги, Девицы и Большой Верейки; Острогожское в бассейнах Тихой Сосны, Потудани и Черной Калитвы и Кантемировское в бассейнах верховьев рек Белая и Богучарка [2].

К Еманчинскому неотектоническому поднятию относятся территории 4 муниципальных районов - Семилукский, Рамонский (частично), Хохольский и Нижнедевицкий. В рельефе Еманчинского неотектонического поднятия различаются три ландшафтных мезозоны.

Вершинно-водораздельная мезозона занимает интервалы абсолютных высот от 200 до 250 метров. Рельефообразующие породы - карбонатные отложения верхнего мела, перекрытые 10-метровой толщей донской морены. Основные экзодинамические явления - водная эрозия и карстовая денудация.

Возвышенно-денудационная мезозона с интервалом высот 160-200 метров. Литология пород песчаные отложения нижнего и верхнего мела. Экзодинамические явления - интенсивная овражная эрозия.

Возвышенно-гидрогенная мезозона (Среднерусский вариант), залегает в диапазоне абсолютных высот в среднем 140-160 метров. Фундамент яруса сложен породами девона (известняки, глины, песчаники), перекрытыми отложениями верхнего мела, на которых сохраняется морена донского ледника. Экзодинамические явления - фронтальные оползни, овражно-оползневые комплексы и овраги.

Особенность мезозоны - ее относительно приподнятое положение в рельефе на возвышенных равнинах. Но гидроморфные свойства ландшафтных комплексов проявляются повсеместно - выходы воклюзов (Сердюков ключ, Крапацкая криница, Серебряные ключи, Большая криница).

Острогожское неотектоническое поднятие территориально приурочено к Острогожскому, Лискинскому (частично), Каменскому, Репьевскому, Россошанскому, Ольховатскому муниципальным районам.

Фундамент Острогожского поднятия сложен породами верхнего мела (писчий мел, мергели), перекрытыми песками, алевритом и киевскими глинами среднего палеогена (эоцен). На самых высоких участках водоразделов с отметками более 220 метров залегают пески верхнего палеогена (олигоцен). До широты Россоши с юга отложения палеогена и неогена перекрыты покровными суглинками и мореной. 
В рельефе Острогожского неотектонического поднятия различаются две ландшафтных мезозоны. Возвышенно-водораздельная мезозона расположена в интервале абсолютных высот 170246 метров. Она выделяется существованием овражно-балочных форм и исключительно широким распространением оползневых явлений, различающихся по морфологии (циркообразные, линейные, глетчеровидные), динамике (оползни отседания, скольжения, течения) и размерам (от нескольких десятков квадратных метров до нескольких гектар).

Водораздельно-денудационная мезозона занимает абсолютные отметки высот от 150 до 170 метров. Рельефообразующие породы - пески среднего палеогена (эоцен). Максимальное распространение получили овражно-балочные формы со следами свежих эрозионных размывов. Редко встречаются следы суффозионных явлений.

На крайнем юге Воронежской области на Среднерусской возвышенности находится Кантемировское неотектоническое поднятие. К нему территориально приурочены 2 муниципальных района - Кантемировский и Богучарский. Рельефообразующие породы, как и на Острогожском поднятии, остаются писчий мел и мергели, обнажающиеся по склонам долинно-балочной сети. А водораздельные местности прикрыты мощным панцирем отложений палеогена и неогена, где особенно выделяется 8 метровая толща песчаников. Песчаноглинистые породы палеогена имеют два водоупоpa, с которыми связано возникновение двухъярусных оползней.

В рельефе поднятия различаются две мезозоны - холмисто-водораздельная с эрозионно-останцовым рельефом и водораздельно-денудационная. Холмисто-водораздельная мезозона занимает изолированные «шпили» (Высокий), горы (Помяловская), сопки (Дзюбина). Мезозона находится в интервалах высот от 190 до 233 метров. Водораздельно-денудационную мезозону образуют овражно-балочная местность, занимающая абсолютные высоты в диапазоне 150-190 метров. Главная особенность экзодинамики - сильный плоскостной смыв. Встречаются места, где после разрушения почвенного покрова и четвертичных суглинков на дневную поверхность обнажаются пески палеогена (с.с. Цапково, Ивановка, Стеценково). Иные экзодинамические процессы в современных условиях из-за распространения близко к дневной поверхности прочных песчаников заметно ослаблены.

Калачское неотектоническое поднятие по проявлению его в структуре рельефа во многом аналогично Острогожскому. Разница заключается лишь в том, что в разрезе палеогена сохранились палеоценовые отложения в виде опок и опоковидных глин, играющие роль водоупора. А пески каневской серии и бучакские пески эоцена образуют водовмещающий слой. Таким образом, вместо эрозионно-суффозионных явлений, что характерно для Острогожского неотектонического поднятия, на этих высотах в Калачеевском поднятии образуется полоса с активным проявлением оползней.

Территориально к Калачскому неотектоническому поднятию относятся Калачеевский, Петропавловский муниципальные районы и группа районов, расположенных на границе с Окско-Донской впадиной - Воробьевский, Таловский, Бутурлиновский, Павловский, Верхнемамоновский.

Явления экзодинамики в этой группе районов весьма специфические. Как уже отмечали, на высотах (160-200 метров) здесь развиты оползни, а на надпойменных террасах Дона и Толучеевки в Петропавловском районе сохраняются массивы песков, подверженные эоловому развеванию («Воронежская Сахара»). Во всех других районах в приречной зоне встречаются значительные площади, занятые овражной эрозией.

Окско-Донская впадина - область относительного тектонического опускания. Литолого-геологическое строение очень простое. С поверхности залегают четвертичные ледниковые и лессовидные отложения - глины и суглинки. А под ними неоген- четвертичные пески. Единственный водоносный горизонт связан с распространением аллювиальных отложений.

В рельефе Окско-Донской низменности высотная дифференциация представлена двумя ландшафтно-высотными мезозонами - высоко-гидрогенной с абсолютными отметками 150-180 метров и низменно-гидрогенной, где высоты не превышают 150 метров.

Высоко-гидрогенная мезозона, занимающая малодренируемые плоскоместья, существует в Бобровском, Аннинском, Панинском, Верхнехавском, Эртильском, Терновском и Таловском муниципальных районах. Спектр экзодинамических явлений невелик - мелкие оползни и бессточные просадочные явления. Спорадически встречаются динамичные овражно-оползневые комплексы. Например, у села Ливенка Павловского района.

Низменно-гидрогенная ландшафтная мезозона расположена в интервале абсолютных высот от 125 метров до 160. Она тяготеет к верховьям рек Плавица, Битюг, Малый Эртиль. Из-за высокого 
процента пахотных земель (более 65 \%) здесь во3можно возникновение ветровой эрозии.

\section{ЗАКЛЮЧЕНИЕ}

Полевой материал, собранный на полустационарных полигонах, фондовый материал сельскохозяйственных предприятий, экспедиционных маршрутных исследованиях, а также материал дистанционного зондирования Земли показывает, что развитие активных экзодинамических явлений в Воронежском модельном регионе очень тесно связано с высотно-ландшафтной дифференциацией равнинного рельефа.

В природной обстановке для возникновения явления экзодинамики, одновременно или следуя друг за другом, действуют обычно несколько факторов, создающих кумулятивный эффект [5].

Экзодинамические явления природного характера водная и ветровая эрозия распространена по территории области повсеместно, но особенно в тех административных районах, которые расположены на возвышенных равнинах - Среднерусской и Калачской.

Овражно-балочные формы рельефа здесь обычное явление. Длина овражно-балочной сети на правобережные Дона и в бассейнах Толучеевки может доходить до 1,5 км/км². Эрозионно-опасные земли со следами активного образования линейных форм встречаются в Семилукском, Нижнедевицком, Хохольском, Острогожском, Россошанском, Калачеевском, Кантемировском и других муниципальных районах (рис. 1, 2). Средняя скорость роста активных овражных вершин доходит до 1-3 метров в год. Но неоднократно нами отмечались случаи скорости прироста значительно превышающие средние данные, когда за год длина вершин увеличивалась на 4-6 метров и более.

В Воронежском регионе известны три типа овражных форм. 1. Висячие овраги, вершины и устья которых располагаются в пределах долинных и балочных склонов. Устья висячих оврагов не доходят до пойм и днищ логов. Поперечный профиль их V-образный. 2. Короткие овраги, вершины которых едва выходят за бровку долинного склона или бровку балочных склонов. Они сохраняют V-образный профиль. Длина их в среднем 150-180 метров. Ширина овражных форм поверху около 50 метров 3. Овраги, рассекающие долинныле и придолинные склонь своими вершинами выходят на приводораздельные участки. Нередко длина таких овражных форм достигает нескольких километров. Поперечный профиль оврагов этого типа более сложный. Чередуются V-образные участки с участками корытообразными и Uобразными.

Плоскостная эрозия - особая форма экзодинамики, снижающая плодородные площади сельскохозяйственных земель. Плоскостной смыв, как явление, встречается на западе и на востоке области. Почвенный снос обычно возникает там, где граница пашни выходит на склоны крутизной $3^{\circ}$ и более. Механизм смыва выглядит следующим образом: 1) снежный покров ложится на мерзлую землю; 2) после многоснежной зимы почва, насыщаясь талой влагой, начинает подниматься как тесто и в какой-то момент, теряя связность, начинает течь. «Черноземные реки» особенно бывают заметными на северных экспозициях мартовскоапрельских снежников.

Ветровая эрозия проявляется эпизодически на всей территории Воронежской области. Если до 50-60-х годов XX века северная граница «черных бурь» проходила по широте Воронежа, то после 70-х годов она сместилась на широту Тулы. Для возникновения разрушения поверхностного слоя почвы должны совпадать три условия. 1. Сухая осень предшествующего года, когда в почве возникает дефицит влаги. 2. Возникновение сильных циркуляционных процессов (ветров). 3. Незащищенность поверхностного почвенного слоя снежным покровом, стерней и т.д. Обычно такие условия для возникновения ветровой эрозии (дефляции) складываются на юге и в центре Русской равнины в конце зимы - начале весны. Последние случаи ветровой эрозии не самого разрушительного характера отмечены на юге Воронежского региона в марте 2013 года.

Оползни в Воронежской области образуются повсеместно в тех местах, где сохраняются отложения глин палеогена и донской морены. Но самый интенсивный оползневой процесс существует в Воронежском Подонье на Среднерусской возвышенности. Севернее широты Воронежа подвижки грунта в основном связаны с залеганием вблизи долинных склонов и склонов крупных балок обводненной морены. Самые динамичные формы оползней известны в Семилукском, Каменском, Лискинском, Калачеевском, Россошанском, Кантемировском районах (рис. 3).

Возникновение оползневого процесса здесь очень тесно связано с явлением овражной эрозии. И тогда в этих местах образуются не чистые эрозионные или оползневые формы, а их сочетание овражно-оползневые комплексы. Образование та- 


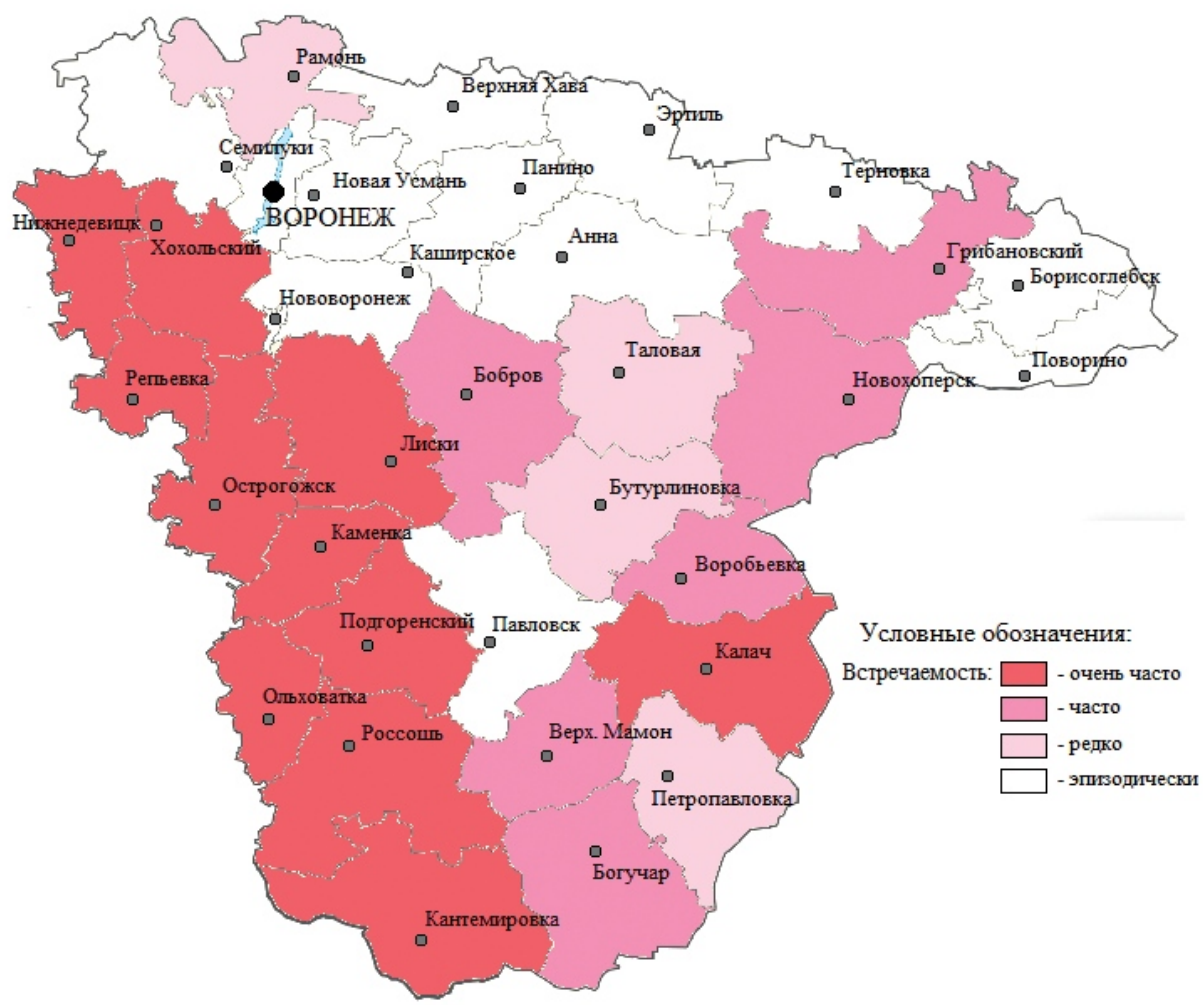

Puc. 1. Экзодинамические явления в муниципальных районах Воронежской области. Овражная эрозия и плоскостной смыв

[Fig. 1. Exodynamic phenomena in the municipal districts of the Voronezh region. Gully erosion and plane washout]

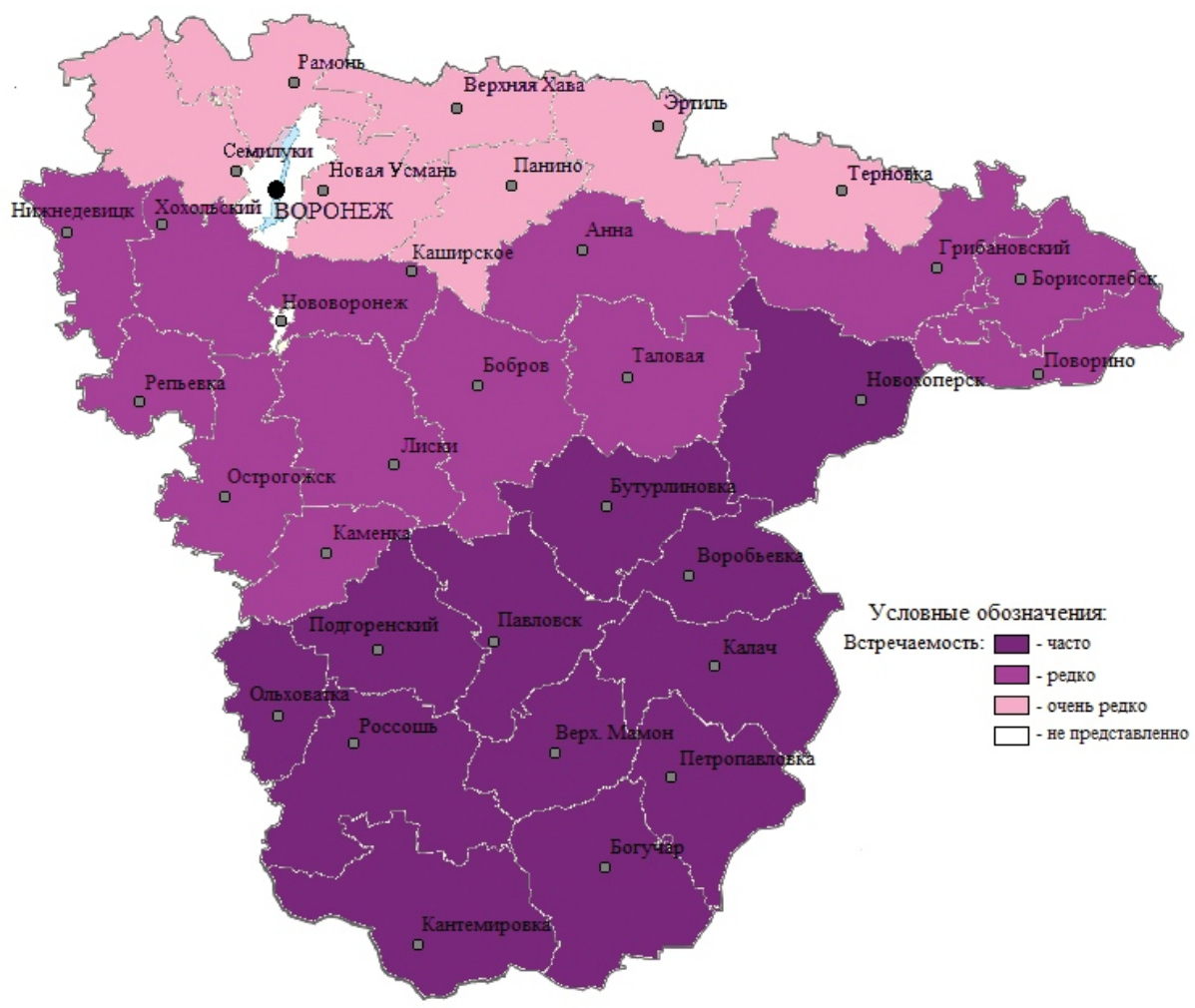

Puc. 2. Экзодинамические явления в муниципальных районах Воронежской области. Ветровая эрозия (дефляция)

[Fig. 2. Exodynamic phenomena in the municipal districts of the Voronezh region. Wind erosion (deflation)] 


\section{С.В. Федотов, С.В. Щербинина}

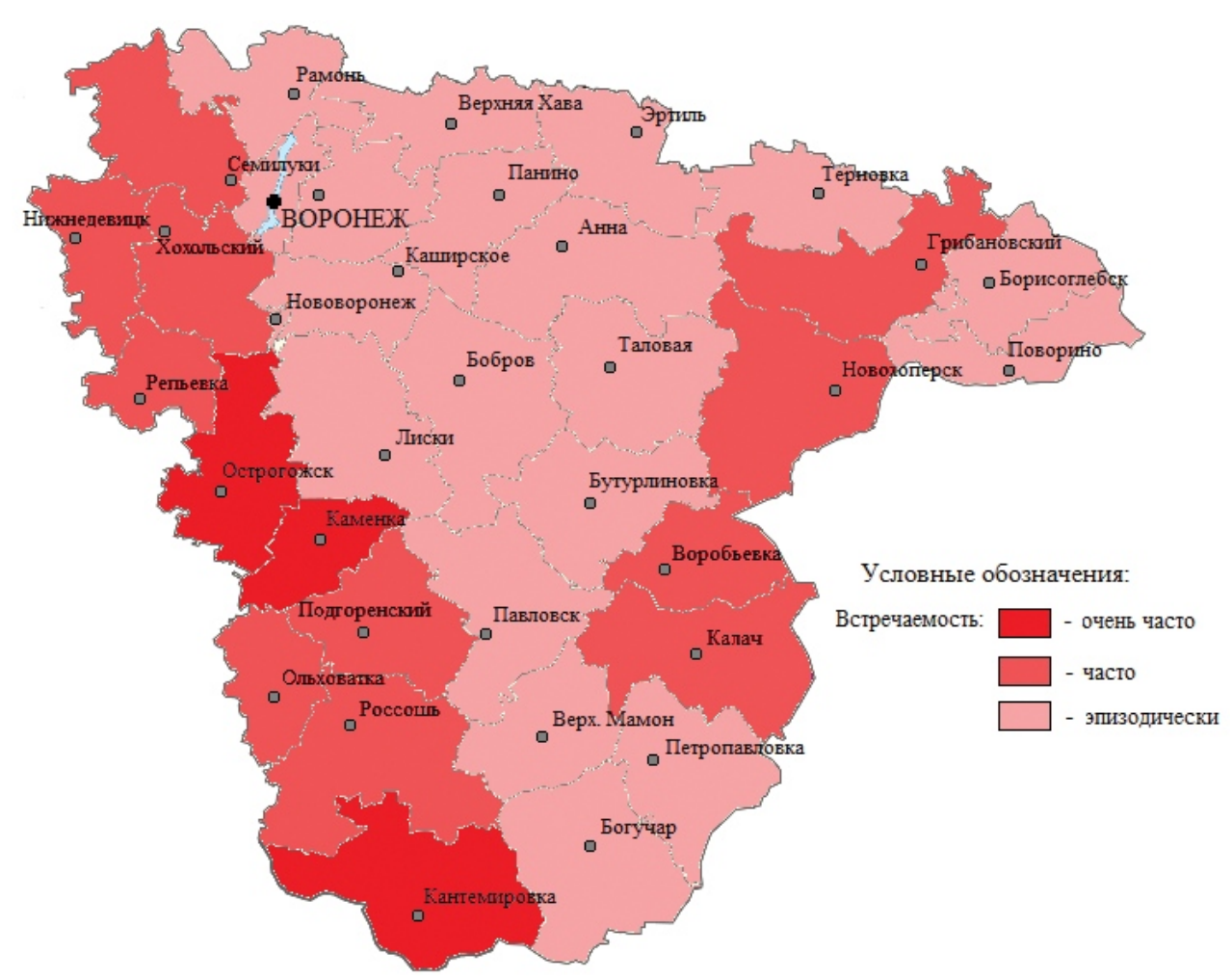

Puc. 3. Экзодинамические явления в муниципальных районах Воронежской области. Оползни и овражнооползневые комплексы

[Fig. 3. Exodynamic phenomena in the municipal districts of the Voronezh region. Landslides and gully-landslide complexes]

ких форм происходит в следующей последовательности: 1) сначала на долинном склоне развивается овражная эрозия; 2) овраги достигают водоупорного слоя, чем нарушают равновесие грунтов - появляются первые признаки подвижки моренных отложений; 3) дальнейший эрозионный врез еще больше активизирует уже начавшийся оползневой процесс и наступает момент развития самостоятельного движения грунта. Скорость подвижки овражно-оползневых тел в среднем составляет 13 м, но бывали годы, когда мы отмечали прирост бровки срыва оползней в направлении водораздела за один весенне-летний сезон на 7-8 метров [4].

Южнее Воронежа оползневые явления одинаково часто возникают в местах моренных отложений и в местах, где сохраняются на водоразделах и вблизи долин рек и логов отложения палеогеновых глин. Южнее южной границы максимального оледенения (Богучарский и Кантемировский районы) оползни развиваются только в местах залегания глин палеогена.

Но особенно интенсивное оползнеобразование известно в Каменском районе. К. С. Оводов [2] счел возможным выделить здесь Евдаковский тип оползней. Механизм развития Евдаковских оползней выглядит следующим образом. Неровная поверхность водоупора из палеогеновых глин влияет на движение водотока в разных направлениях. Если движение подземного потока совпадает с топографическим уклоном, то лежащие над ним слои пород начинают ползти. Оползни развиваются на больших площадях и очень энергично. Чаще всего образуются оползневые цирки. Площадь некоторых оползневых цирков достигает 2 га и более.

Оползни становятся главной причиной разрушения домовладений, линий электропередач, нарушения движения транспорта на автомобильных магистралях.

После завершения строительства автомагистрали Москва - Ростов-на-Дону движению транспорта южнее Воронежа многие годы мешал Шестаковский оползень на правобережье реки Битюг. Моренный материал в весеннее - летний сезон постоянно перекрывал одну колею автомобильной дороги, создавая труднопреодолимые препятствия большегрузному транспорту. Противооползневые меры, предпринимаемые службами Воронежского управления автомобильной дороги Воронеж Ростов-на-Дону, не давали многие годы положительного результата. Только после того как по на- 


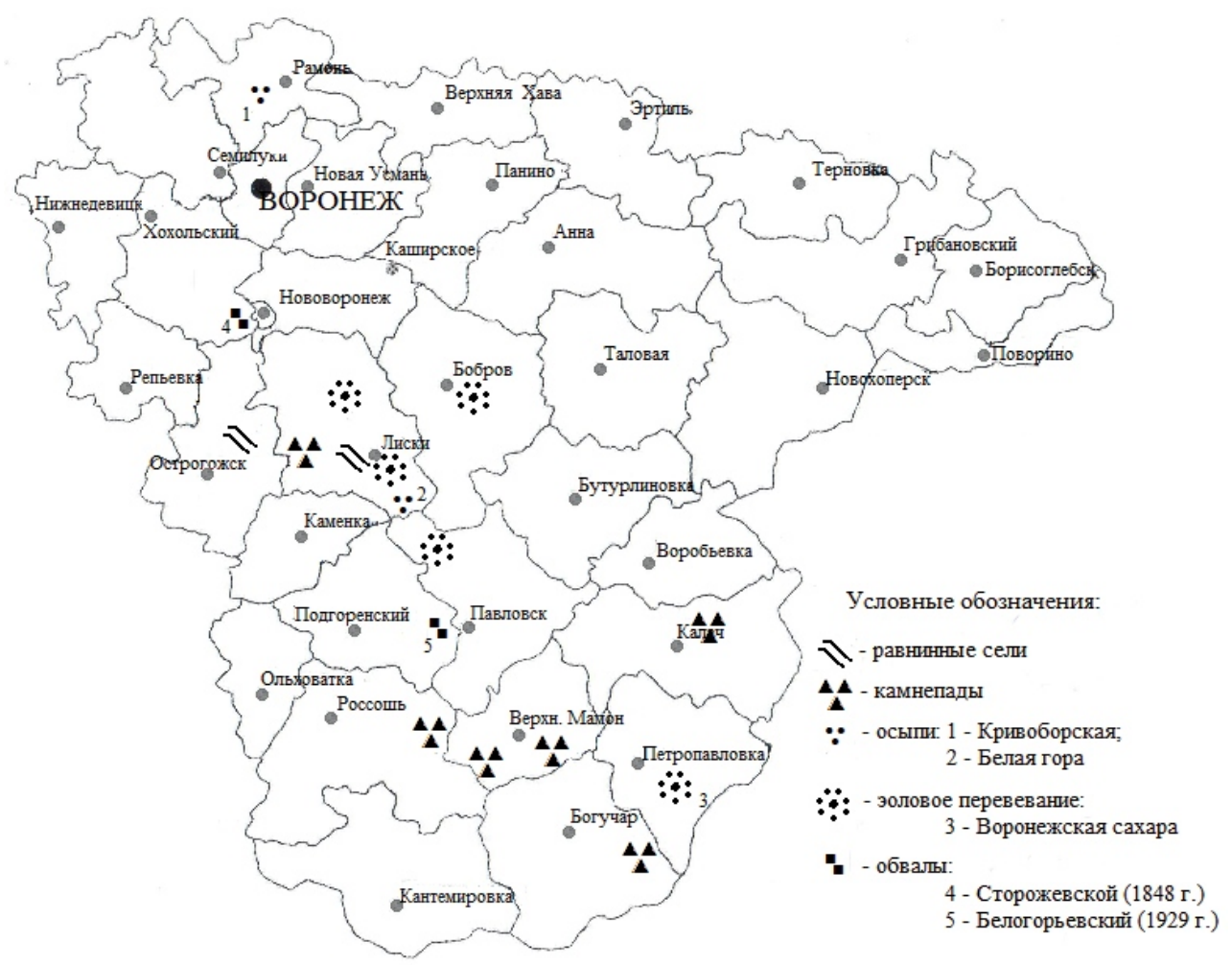

Puc. 4. Экзодинамические явления в муниципальных районах Воронежской области. Равнинные сели, камнепады, осыпи, эоловое перевевание, обвалы

[Fig. 4. Exodynamic phenomena in the municipal districts of the Voronezh region. Plain mudflows, rockfalls, talus, aeolian rolling, landslides]

шему совету была полностью удалена морена со склона выемки автомобильного полотна до подстилающего ее писчего мела проблема оползня у с. Шестакова была разрешена. Сегодня Шестаковский оползень забыт всеми автомобилистами.

Активный оползень в настоящее время реально угрожает автодорожной магистрали Каменка Марки [3].

Равнинные сели - относительно новый вид экзодинамических явлений в Воронежской области [5]. Равнинные сели - миниатюрная модель разрушительных селей в горах. Чаще всего они регистрируются на сравнительно небольшом участке правобережья Дона и Тихой Сосны (рис. 4).

Возникновение селей происходит при совпадении двух условий. Во-первых, должно произойти накопление выветрившейся меловой щебенки. Во-вторых, скоротечное развитие циркуляционных процессов ливневого характера. Когда эти два условия совпадают, то по логам, выходящим устьями в долины Тихой Сосны и Дона, несутся потоки мутной воды, жидкой грязи с включениями глыб мела и меловой щебенки, погребая под собой огороды, сады, луга, постройки. Забивают коллекторы под полотном железной дороги Лиски - Валуй- ки, выплескиваются на поверхность колеи, останавливая на несколько часов движение транспорта.

Воронежский регион в Центральном Черноземье не единственное место, где эпизодически возникают равнинные сели. Так, 29 июня 1882 года между городами Чернь и Мценск Тульской губернии грязевой сель после сильного ливня разрушил водоспускное сооружение под железнодорожным полотном Московско-Курской магистрали. Результат - массовая гибель пассажиров. Эта трагедия в истории железных дорог России известна как Кукуевская катастрофа [1].

Камнеnaдbl - еще одна опасная форма экзодинамики, встречаемая, на территории Воронежского региона (рис. 4) от с. Костенки (Хохольский район) до с. Белая Горка (Богучарский район). Растрескавшиеся монолиты мела в урочищах «стенки» под действием силы тяжести скатываются к подножию склонов, создавая подобие курумовых массивов в горах. Там, где железнодорожная магистраль проходит близко от подножью меловых обрывов, камнепады создают угрозу движению поездов.

Служба пути Лискинского отделения Юго-Восточной железной дороги, чтобы обезопасить дви- 


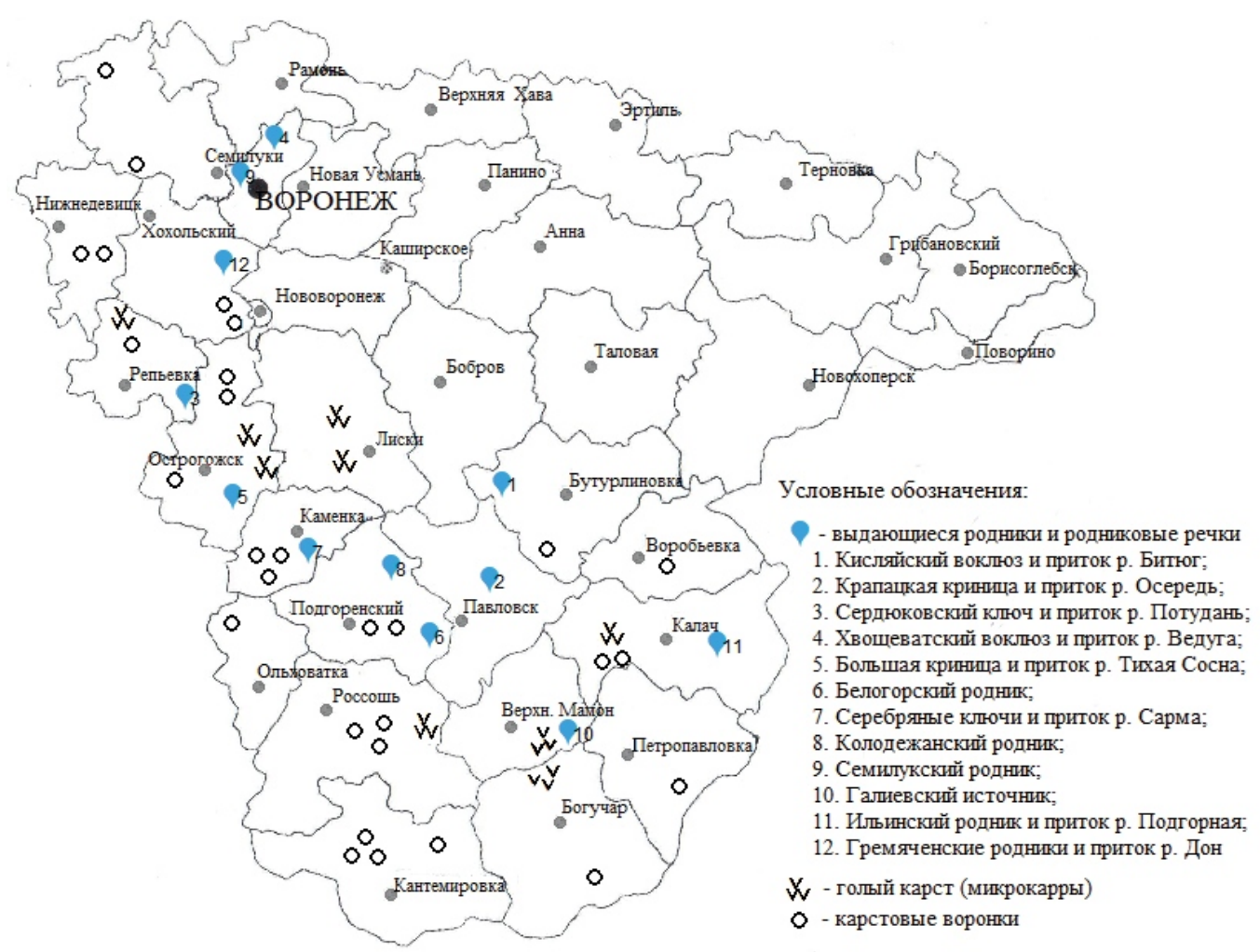

Puc. 5. Экзодинамические явления в муниципальных районах Воронежской области. Карстовая денудация

[Fig. 5. Exodynamic phenomena in the municipal districts of the Voronezh region. Karst denudation]

жение транспорта устраивает в местах схода камнепадов защитные заграждения.

Ocblneй на территории области немного. А те, которые известны, приурочены к уступам 3 и 4 надпойменных террас Дона. Самые впечатлительные - Кривоборское обнажение в Рамонском районе и Белая гора в Лискинском (рис. 4).

Обваль в Воронежском Подонье находятся в двух местах. Первый обвал, как сообщал журнал «Отечественные записки» в июне 1848 года, произошел у с. Сторожевое - 1 (Хохольский район) на правобережье Дона. Обвалившиеся крупные глыбы писчего мела и перекрывающие его палеогеновые и моренные отложения перекрыли значительную часть русла реки.

Второй аналогичный обвал возник в 1929 году на правобережье Дона у с. Белогорье Подгоренского района. Как и у с. Сторожевое обвалившиеся меловые породы заметно сузили русловую часть реки (рис. 4).

Причина обвалов предположительно связана с постепенным выносом из-под монолита писчего мела обводненных песков, залегающих на уровне речных вод Дона. В какой-то момент нарушается устойчивость мелового монолита и происходит его отседание от коренного долинного склона.
Есть признаки возникновения нового обвала на правобережье Дона у села Колыбелка Лискинского района.

Карстовая денудация в Воронежской области, как и в других административных субъектах центра Европейской России, получила распространение в местах залегания карбонатных пород. В Воронежском регионе карстуется преимущественно белый писчий мел. Следы карстовой денудации встречаются во всех административных районах на Среднерусской и Калачской возвышенностях (рис. 5). Открытый карст представлен провальными воронками и голым карстом (микрокары известны на обнаженных массивах мела у Дивногорья, Коротояка, Калача, Деризовки, Нижнего Карабута, Семмейки). Подземное карстование определяется опосредовано, о чем свидетельствуют выходы на дневную поверхность родников и начинающихся от них родниковых речек (Сарма, Сердюковка, Кисляй и другие). Активное подземное растворение мела подтверждается высоким содержанием карботанов в родниковой воде.

\section{СПИСОК ЛИТЕРАТУРЫ}

1. Гиляровский В.А. Репортерство // Мои скитания, 1998, с. 199 - 229. 
2. Земля Воронежская / науч. ред. В.И. Федотов. Воронеж: Воронежский государственный университет, 2006. $531 \mathrm{c}$.

3. Разиньков Н.Д., Титова С. Л. Оползневая опасность и своевременность ее восприятия: региональный опыт // Вестник Воронежского государственного университета. Серия География. Геоэкология, 2020, № 1, c. 108-114. DOI: https://doi.org/10.17308/geo.2020.1/2668
4. Федотов В.И., Федотов С. В. Пособие к проведению учебной полевой физико-географической практики на полигоне «Семилукский». Воронеж, 2003. 68 с.

5. Федотов В.И., Федотов С. В. Современные экзодинамические процессы в Воронежском Подонье // Вестник Воронежского государственного университета. Серия: Геология, 2019, № 1, с. 15-20.

Конфликт интересов: Авторы декларируют отсутствие явных и потенциальных конфликтов интересов, связанных с публикацией настоящей статьи.

Поступила в редакиию 29.11.2020

Принята к публикащии 20.11.2020

\title{
THE STUDIES OF VORONEZH LOCAL LORE
}

\section{High-Altitude Landscape Mesozones and Exodynamic Phenomena in Voronezh Model Region}

\author{
S. V. Fedotov ${ }^{凶}$, S. V. Shcherbinina \\ Voronezh State University, Russian Federation \\ (1, Universitetskaya Sq., Voronezh, 394018)
}

\begin{abstract}
The aim of the research is to reveal the confinement of exodynamic phenomena in the Voronezh model region to high-altitude landscape mesosons of plains. Materials and methods. Source materials for analytical generalizations were field observations at semi-stationary ranges located in the Voronezh Don Region, expeditionary route observations and materials for interpretation of space images. Results and discussion. Field materials, agricultural enterprise funds, semi-stationary observations and remote sensing results show that exodynamic phenomena in the Voronezh model region are very closely related to the altitude and landscape differentiation of the plain relief. For example, water and wind erosion is widespread throughout the region. However, it is most often found within the boundaries of elevated-denudation and vertex-water-separated mesozoans in the Central Russian and Kalachskaya Uplands. In the Oka-Don Plain, wind erosion is observed in areas of high land tillage in the lowland-hydrogen mesozone in the upper reaches of the rivers Plavica, Bityug and Maly Ertil. The main exodynamic phenomena on the Central Russian Upland are water erosion and karst denudation, where the vertex-water separating mesozone (200-250 metres) has spread. Conclusions. Our numerous studies show that in the Voronezh model region there is a full list of exodynamic phenomena known in the administrative areas of the centre of the Russian Plain - ravine and water erosion, landslides, mudslides, landslides, karst denudation, plain mudflows, rockfalls.
\end{abstract}

Key words: high-altitude mezzanine, exodynamic processes, elevation, lowland, plain, neotectonics.

For citation: Fedotov S. V., Shcherbinina S. V. High-altitude landscape mesosons and exodynamic phenomena in Voronezh model region. Vestnik Voronezskogo gosudarstvennogo universiteta. Seria Geografia. Geoekologia, 2020, No. 4, pp. 69-78. (In Russ.) DOI: https://doi.org/10.17308/geo.2020.4/3067

(C) Fedotov S. V., Shcherbinina S. V., 2020

\Sergey V. Fedotov, e-mail: fsv777@yandex.ru

(c) (i) The content is available under Creative Commons Attribution 4.0 License. 


\section{REFERENCES}

1. Gilyarovskiy V. A. Reporterstvo [Reporterstvo] // Moi skitaniya, 1998, pp. 199 - 229. (In Russ.)

2. Zemlya Voronezhskaya [Voronezh Land] / Ed. V. I. Fedotov. Voronezh: Voronezhskiy gosudarstvennyy universitet, 2006. 531 p. (In Russ.)

3. Razin'kov N.D., Titova S.L. Opolznevaya opasnost' i svoevremennost' ee vospriyatiya: regional'nyy opyt [Landslide Hazard and Timeliness of its Perception: Regional Experience] // Vestnik Voronezskogo gosudarstvennogo universiteta. Seria Geografia. Geoekologia, 2020, no. 1, pp. 108-114. (In Russ.) DOI: https://doi.org/10.17308/geo.2020.1/2668

\section{Федотов Сергей Владимирович}

кандидат географических наук, доцент, заведующий кафедрой рекреационной географии, страноведения и туризма Воронежского государственного университета, г. Воронеж, Российская Федерация, ORCID: https://orcid.org/0000-0002-4969-7166, e-mail: fsv777@yandex.ru

Щербинина Светлана Васильевна

кандидат географических наук, доцент кафедры природопользования факультета географии, геоэкологии и туризма Воронежского государственного университета, г. Воронеж, Российская Федерация, ORCID: https://orcid.org/0000-0001-5022-4385, e-mail: svetas237@mail.ru
4. Fedotov V.I., Fedotov S. V. Posobie k provedeniyu uchebnoy polevoy fiziko-geograficheskoy praktiki na poligone "Semilukskiy" [Manual for Field Training of Physical and Geographical Practice at Semiluksky Range]. Voronezh, 2003. 68 p. (In Russ.)

5. Fedotov V.I., Fedotov S. V. Sovremennye ekzodinamicheskie protsessy v Voronezhskom Podon'e [Modern Exodynamic Processes in the Voronezh Don Region] // Vestnik Voronezhskogo gosudarstvennogo universiteta. Seriya Geologiya, 2019, no. 1, pp. 15-20. (In Russ.)

Conflict of interest: The author declares no information of obvious and potential conflicts of interest related to the publication of this article.

Received: 29.11.2020

Accepted: 20.11.2020

Sergey V. Fedotov

Cand. Sci. (Geogr.), Associate Professor, Head of the Department of recreational geography, country studies and tourism, Faculty of Geography, Geoecology and Tourism, Voronezh State University, Voronezh, Russian Federation, ORCID: https://orcid.org/0000-0002-4969-7166, e-mail: fsv777@yandex.ru

Svetlana V. Shcherbinina

Cand. Sci. (Geogr.), Associate Professor of the Department of nature management, Faculty of Geography, Geoecology and Tourism, Voronezh State University, Voronezh, Russian Federation, ORCID: https://orcid.org/0000-0001-5022-4385, e-mail: svetas237@mail.ru 